\title{
Prehistoric Birds from Rurutu, Austral Islands, East Polynesia ${ }^{1}$
}

\author{
David W. Steadman ${ }^{2,4}$ and Robert Bollt ${ }^{3}$
}

\begin{abstract}
We identify 70 bird bones from the Peva dune site, Rurutu, Austral Islands. These bones represent 10 species, dominated by the extant White-tailed Tropicbird, Phaethon lepturus; the nonnative chicken, Gallus gallus; and an undescribed species of extinct rail, Gallirallus sp. Two other species are extinct (the ground-doves Gallicolumba undescribed spp. 1 and 2). No species of Gallirallus or Gallicolumba has been recorded previously from the Austral Islands. All but three of the 70 bird bones are from the lowest cultural strata at Peva, which date from the thirteenth to early fifteenth century A.D. (the Archaic or Early East Polynesian cultural phase). The small set of bird bones from the Peva dune site increases the number of indigenous species of land birds known from Rurutu from three to six.
\end{abstract}

The modern native birds of the Austral Islands are few in species and patchily distributed among the islands (Steadman 2006: tables 7-10). On Rurutu Island, in particular, only six species of seabirds certainly or probably nest today (the frigatebirds Fregata minor and $F$. ariel, the tropicbirds Phaethon lepturus and $P$. rubricauda, and the noddies Anous stol$i d u s$ and $A$. minutus), whereas the only resident "land birds" are three aquatic species (the duck Anas superciliosa, heron Egretta sacra, and crake Porzana tabuensis [Raust et al. 2002]). In this paper, we analyze the bird bones that R.B. recovered from Peva dune, an archaeological site on Rurutu that he excavated in 2003. We focus on the stratigraphic, chronologic, cultural, and biogeographic con-

\footnotetext{
${ }^{1}$ Financial support was provided by the National Science Foundation (grants EAR-9714819 and DEB0228682 to D.W.S., grant BCS04-37581 to R.B.). Manuscript accepted 26 May 2009.

${ }^{2}$ Florida Museum of Natural History, University of Florida, Gainesville, Florida 32611.

${ }^{3} 400$ Hobron Lane, Apt. 1715, Honolulu, Hawai'i 96815.

${ }^{4}$ Corresponding author (phone: 352-273-1968; e-mail: dws@flmnh.ufl.edu).
}

Pacific Science (2010), vol. 64, no. 2:315-325

doi: $10.2984 / 64.2 .315$

(C) 2010 by University of Hawai'i Press

All rights reserved text of the 10 species of birds recovered from the site. The three extinct species of land birds from the Peva dune site will be described taxonomically in a separate paper.

The Austral Islands are a roughly linear set of seven islands in the south-central part of East Polynesia (Figure 1). They consist of five high islands (Rimatara, Rurutu, Tubuai, Ra'ivavae, and Rapa) as well as the westernmost uninhabited Maria Atoll and the Marotiri Rocks near Rapa. The archipelago is actually the eastern half of the Cook-Austral chain (Dickinson 1998) (Figure 1). Defining the southern boundary of central East Polynesia, the Australs are more temperate than the Society Islands to the north and the southern Cook Islands to the northwest. The Australs have the smallest total landmass of any archipelago in Polynesia except for the Pitcairn Group. The largest island, Tubuai, has an area of only $45 \mathrm{~km}^{2}$ and an elevation of $422 \mathrm{~m}$. The annual rainfall is between 1,800 and 2,000 $\mathrm{mm}$, and drought is not typically a problem (ORSTOM 1993).

Rurutu (Figure 2) is the second largest island in the group. It lies $472 \mathrm{~km}$ southeast of Tahiti at $151^{\circ} 21^{\prime} \mathrm{W}, 22^{\circ} 27^{\prime} \mathrm{S}$. Rurutu is a partial makatea (uplifted coral limestone) island with a land area and elevation of ca. $38.5 \mathrm{~km}^{2}$ and $389 \mathrm{~m}$ (Stoddart and Spencer 1987, Maury et al. 2000:11). The island began to form ca. 12 million yr ago, most likely from an underwater hotspot now located near Ra'ivavae. A little over 1 million yr ago 


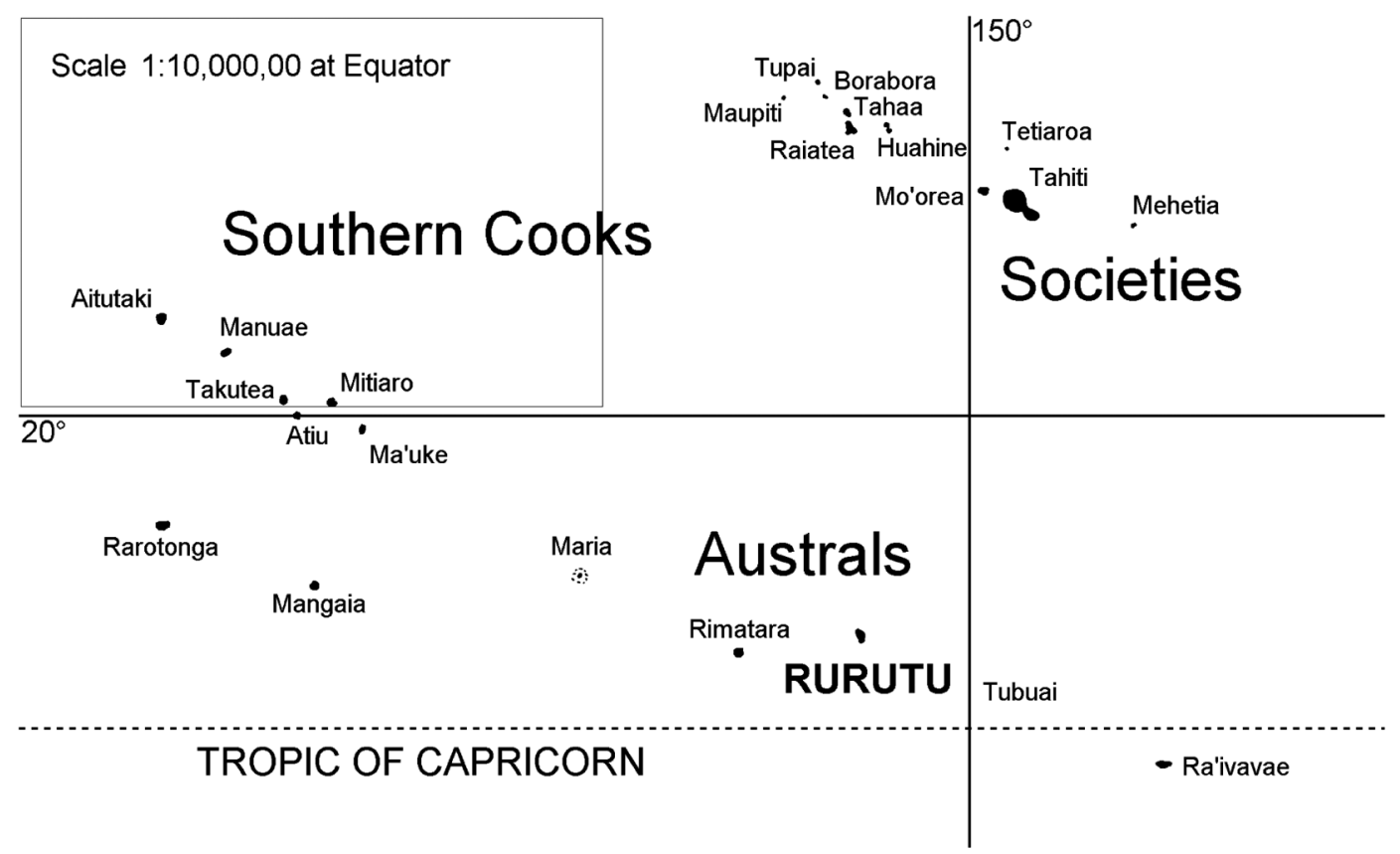

Figure 1. The southwestern portion of eastern Polynesia, including the Society, Cook, and Austral islands.

Rurutu passed over another hotspot, initiating a second period of volcanism that uplifted the island and deposited fresh lava on its surface (Bonneville et al. 2002). Subsequent uplift accounts for the makatea, which covers ca. $28 \%$ of Rurutu today (Stoddart and Spencer 1987).

The small size of the Australs has contributed to its degraded vegetative state. Rurutu in particular was heavily deforested at European contact. James Cook (1955:155), the first European to reach the Australs, sighted Rurutu on 14 August 1769. Cook's crew did not try to reach shore because of the lack of a good anchorage and the unfriendly nature of the inhabitants. Accompanying botanist Joseph Banks (1962:332) wrote, "The Island to all appearance that we saw was more barren than any thing we have seen in these seas." The volcanic bedrock still is covered mostly by secondary vegetation, with slopes dominated by pyrophytic growth on highly eroded soils, notably Miscanthus grass and, in the higher altitudes, Dicranopteris ferns. Most of these areas are useless for cultivation, which is concentrated in the valleys.

A narrow fringing reef encircles Rurutu, and only two passes (located at Moerai and Avera) are large enough to accommodate a sizeable ship. The makatea cliffs form, in some cases, natural barriers between the valleys. The makatea consists of six large limestone blocks and at least 16 smaller ones (Figure 2) that trap sediment in the swampy valley floors, which are well suited for taro cultivation (Stoddart and Spencer 1987). Apart from the makatea cliffs, the topography is accessible. Considering the impoverished vegetation, which undoubtedly was subjected to human-set fires in the dry season, it is reasonable to postulate that most indigenous species of vertebrates on Rurutu faced rapid extinction after human colonization.

Until now, the prehistoric data on land birds in the Austral Islands consisted only of a single tibiotarsus of fruit-dove (Ptilinopus undescribed sp.) from Tubuai (Steadman 2006:227-229, 334). 


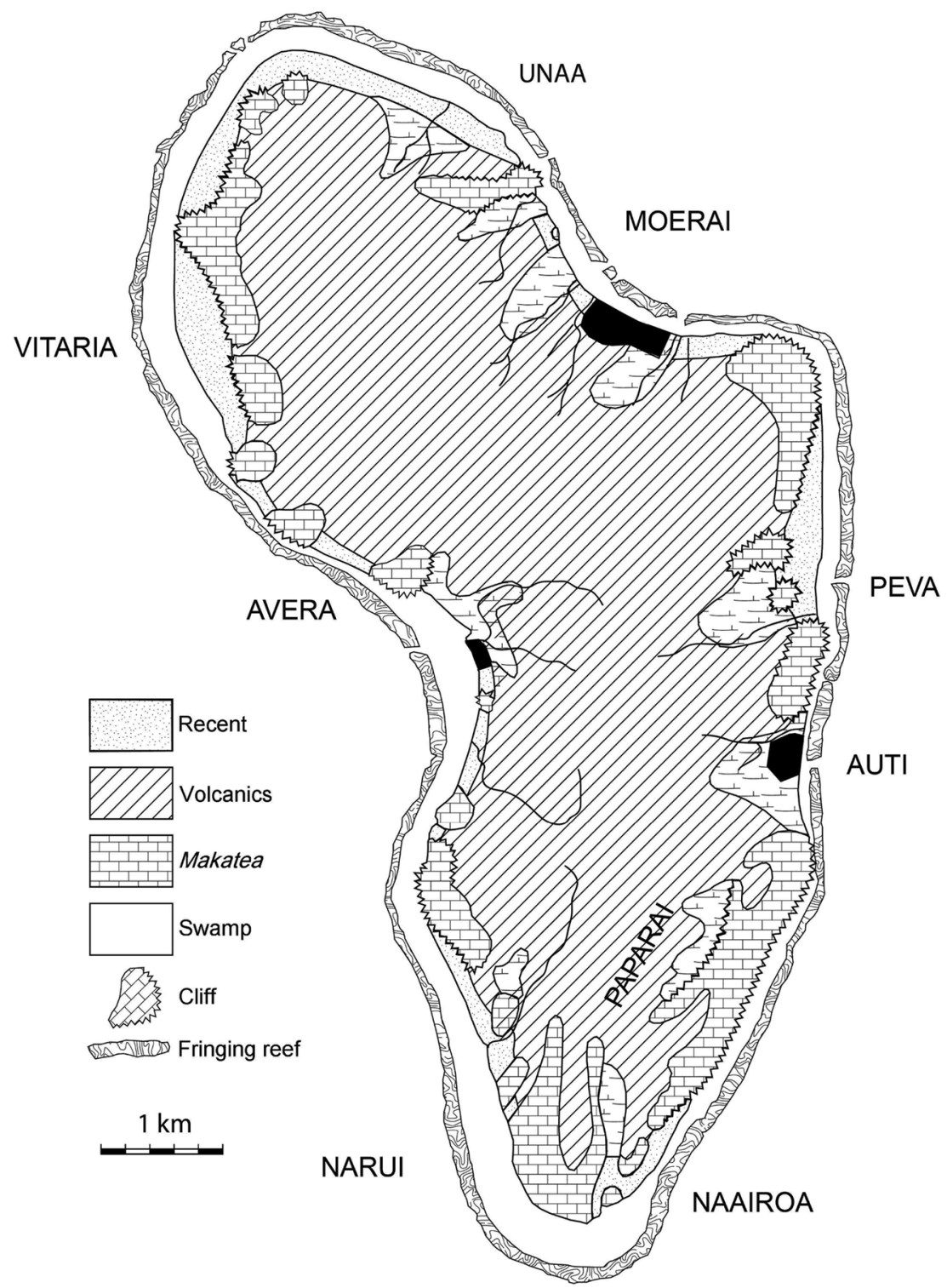

Figure 2. Rurutu. The three modern villages are in black.

\section{Site Setting, Excavation, and Chronology}

The Peva dune site (ON1) on Rurutu was excavated by Bollt and local assistants during May-August 2003. All deposits were screened through $3.2 \mathrm{~mm}$ (1/8 inch) mesh. In D.W.S.'s experience at many other archaeological sites in Oceania, there is very little if any difference in the number of species of birds recovered using $3.2 \mathrm{~mm}$ mesh versus $1.6 \mathrm{~mm}$ (1/16 inch) mesh, whereas using screens with mesh no finer than $6.4 \mathrm{~mm}$ (1/4 inch) clearly undersamples the prehistoric avifauna. The site yielded a rich artifact and faunal assem- 
blage. All artifacts recovered in situ were plotted on unit maps. Cultural features such as earth ovens were photographed and mapped, as were wall profiles. Full details of the excavation are presented in Bollt $(2008 a, b)$.

Areal excavation (a total of $33 \mathrm{~m}^{2}$ ) proceeded in two places, Area 1 and Area 2 (Figure 3), each with two distinct cultural deposits. Area 2, where most effort was focused, yielded the richest deposits. The lower cultural stratum, which dates from the late thirteenth to early fifteenth century A.D., represents the Early East Polynesian (EEP) or Archaic period. The upper cultural layer, associated with a marae complex, was deposited during the Late East Polynesian (LEP) or Classic period (eighteenth to early nineteenth century A.D.), which lasted until evangelization in 1823. The two cultural deposits are separated by a thick layer of sterile beach sand. From one prehistoric period to the next, major changes took place in material culture and subsistence. Sociopolitical changes also are reflected in the archaeological record, including evidence for feasting and wealth. The Peva dune site offers the first such reference point for the Australs.

The five stratigraphic layers at Peva (Figure 4) are generally consistent across the site. The lower cultural deposit (Layer D; Peva Phase I) corresponds to the EEP period; the upper two (Layers A, B; Peva Phase II) represent the LEP period.

LAYER A. Very dark grayish brown (10YR 3/1) loamy sand. This topsoil seldom exceeded $15 \mathrm{~cm}$ in depth. The abundant pig and turtle remains were clearly associated with a marae where ritual feasting took place. The midden began at a depth of $2-3 \mathrm{~cm}$ below the surface and continued throughout Layer A. Pavement stones of coral and basalt represent the original surface of the marae grounds, which extended as far as the excavation proceeded and probably farther.

LAYER B. Yellowish brown (10YR 5/4) sand. Layer B was a mixture of the topsoil of Layer A and the sand of Layer C; it was indistinguishable from Layer $\mathrm{A}$ in midden and other cultural content. The absence of Layer
B in Area 2 might be related to the dense tree canopy that allows less rain directly through than at the exposed marae area, thus preventing mixture of the topsoil and sand.

LAYER C. Pale yellow (2.5Y 7/4) sand, culturally sterile. The $\mathrm{B} / \mathrm{C}$ and $\mathrm{A} / \mathrm{C}$ interfaces were abrupt and unambiguous. Layer $\mathrm{C}$ had no cultural content.

LAYER D. Light to dark olive brown (2.5YR 5/3-4/4) sand, compact and charcoal stained, with abundant midden and artifacts. The C/D interface was abrupt. Layer D represents the EEP deposit and contained abundant shell and bone midden, pearlshell artifacts, basalt flakes, and adzes. Most artifacts are typologically distinctive of the EEP period. Coral pavement stones and postholes suggest a structure of indeterminate shape.

LAYER E. Pale yellow (2.5Y 7/4) sand. This culturally sterile beach sand was identical to Layer $\mathrm{C}$ and contained some coral fragments and water-rolled shell, clearly a part of the original dune matrix. The $\mathrm{D} / \mathrm{E}$ interface was abrupt; cultural remains did not penetrate Layer E, which represents the natural sand dune before human occupation.

Seven charcoal samples from the EEP deposit at Peva (Layer D) were analyzed for AMS radiocarbon $\left({ }^{14} \mathrm{C}\right)$ dating, one by Beta Analytic Inc., and six by National Ocean Sciences Accelerator Mass Spectrometry Facility (NOSAMS) at Woods Hole Oceanographic Institute (Bollt 2008a: table 1). At $2 \sigma$, these seven age estimates collectively range from Cal A.D. 1219 to 1415 , a remarkably narrow time interval that overlaps with that of EEP sites in the southern Cook Islands such as the Anai'o site on Ma'uke (Walter 1998), Ureia and Moturakau sites on Aitutaki (Allen and Schubel 1990, Allen and Steadman 1990, Allen and Wallace 2007), and Tangatatau Rockshelter on Mangaia (Kirch et al. 1995, Steadman 2006:79-82). The absence of charcoal from the LEP period (Layers $\mathrm{A}, \mathrm{B}$ ) prohibits ${ }^{14} \mathrm{C}$ dating, but the context of the marae and its associated midden and artifacts strongly suggests an occupation during the eighteenth and early nineteenth centuries (Bollt 2008a). 


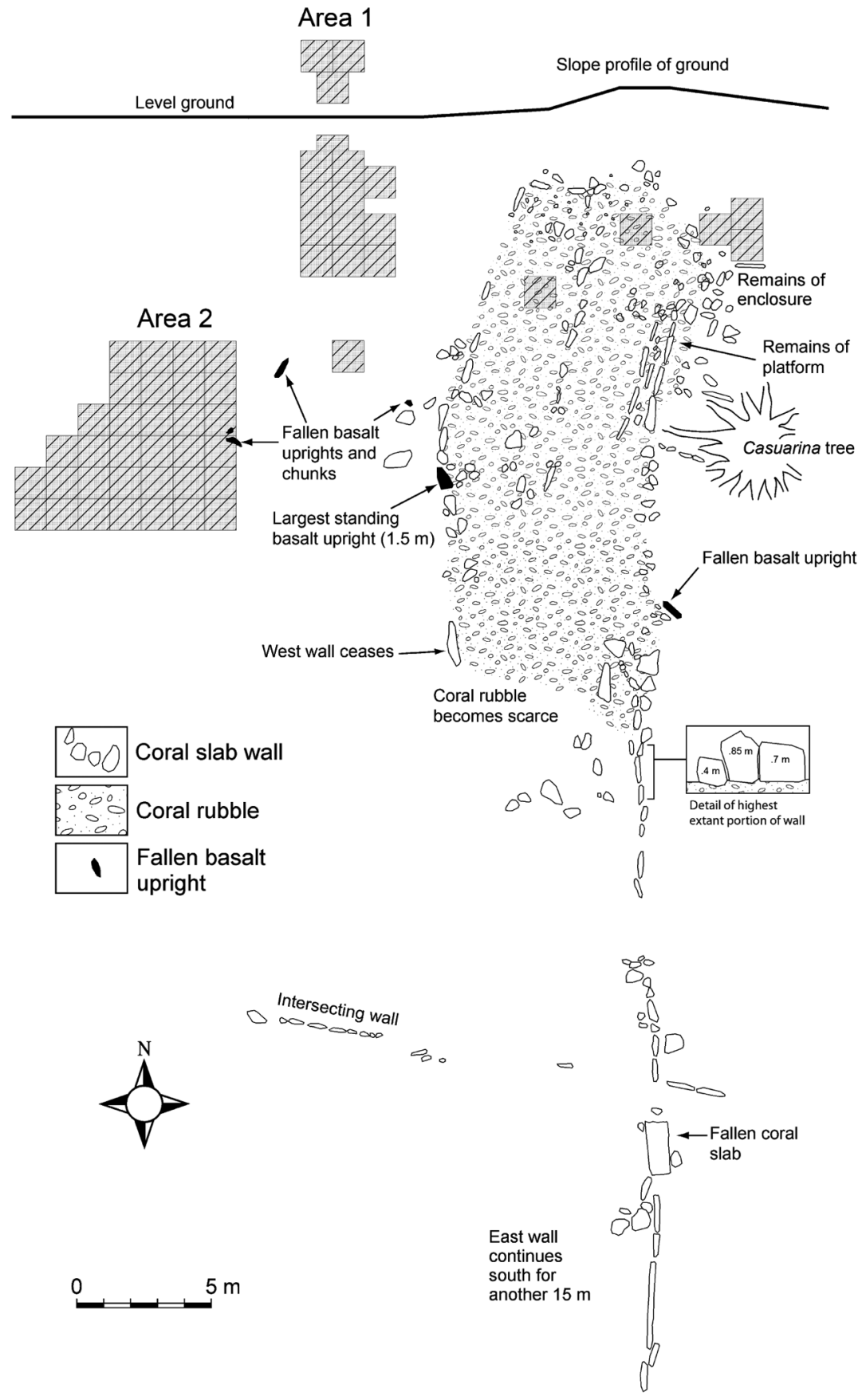

Figure 3. Plan view of the Peva dune site, Rurutu. 
Area 1, South wall
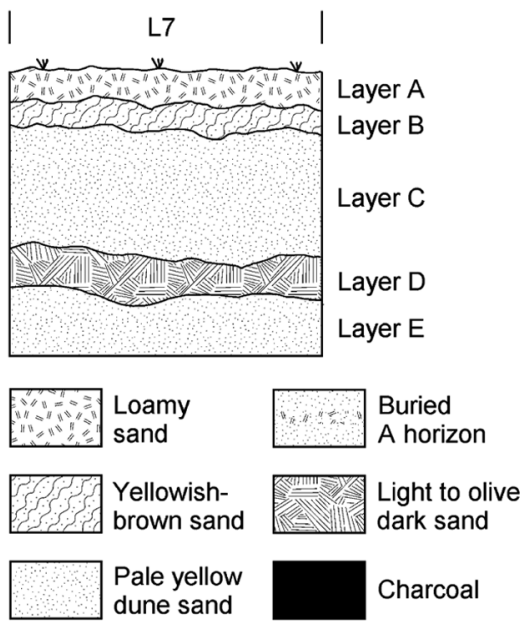

Area 2, South wall

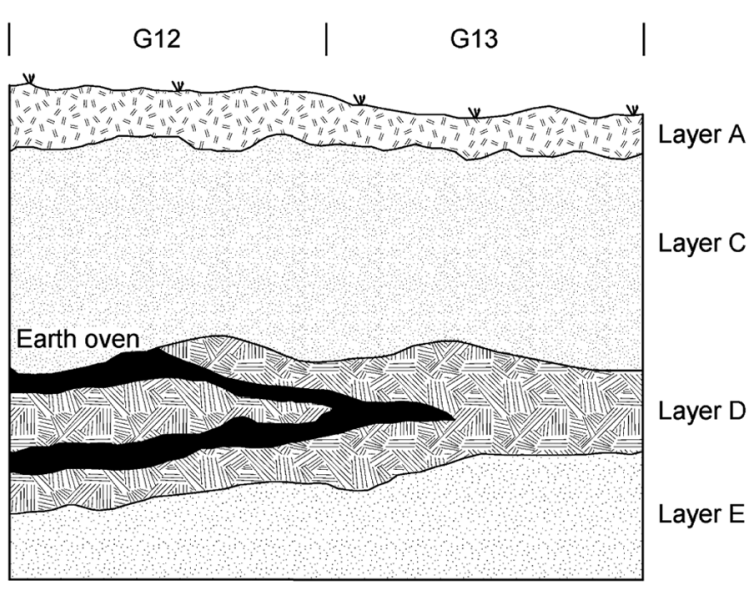

Area 2, West wall

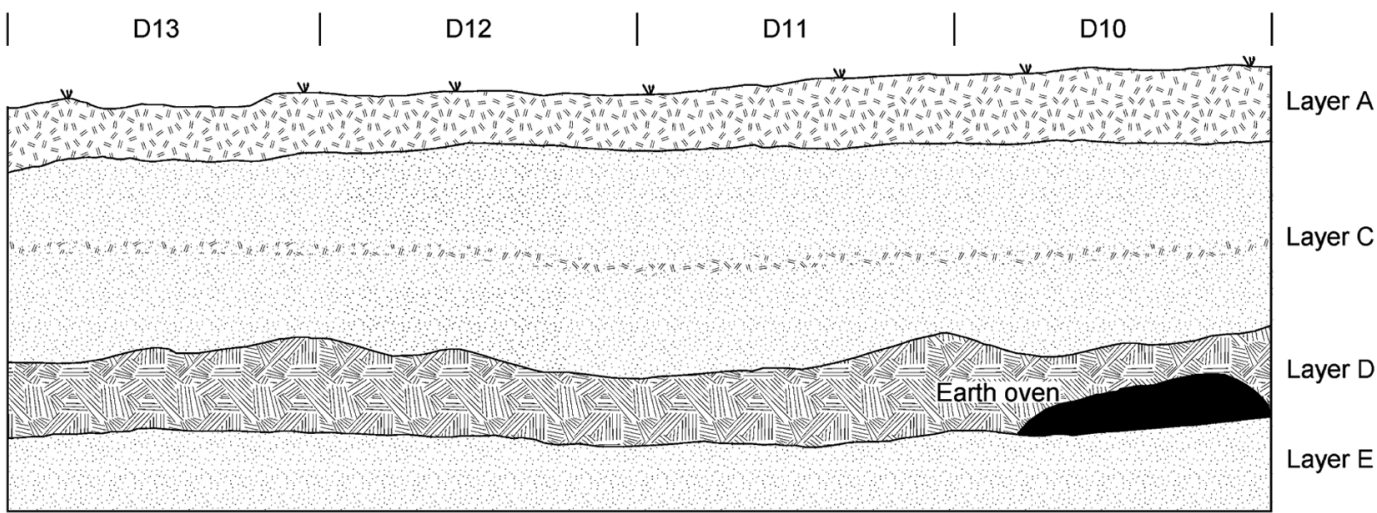

Figure 4. Stratigraphic profile of Areas 1 and 2, Peva dune site, Rurutu. The primary cultural strata are Layer B (LEP) and Layer D (EEP).

\section{MATERIALS AND METHODS}

All bone from the Peva dune site was recovered, but here we report only the abundant bone from Area 2 because the EEP deposit of Area 1 consisted almost entirely of mussel shell rather than bone. The EEP deposit in Area 2 was far richer in invertebrate remains as well as bone. The prehistoric bird bones were identified by D.W.S. through direct comparison with modern skeletons in the collection of the Florida Museum of Natural History, University of Florida (UF), and previously identified prehistoric bones from UF and the Bernice P. Bishop Museum. Our bone data are presented as the number of identified specimens (NISP).

\section{RESULTS}

The 70 bird bones identified to the species level have NISP values of 30 for native seabirds, 25 for native land birds, and 15 for the nonnative chicken, Gallus gallus (Table 1). Just three species (White-tailed Tropicbird, Phaethon lepturus; the undescribed species of extinct rail, Gallirallus sp.; and chicken) account for $71 \%$ of the total bird NISP. 
TABLE 1

Bird Bones Identified from Area 2, Peva Dune Site, Rurutu (Values Are NISP)

\begin{tabular}{|c|c|c|}
\hline Species & Archaic or EEP (Phase I) & Classic or LEP (Phase II) \\
\hline \multicolumn{3}{|l|}{ Seabirds } \\
\hline Phaethon rubricauda, Red-tailed Tropicbird & - & 2 \\
\hline Phaethon lepturus, White-tailed Tropicbird & 18 & - \\
\hline Sula sp., unidentified booby & 1 & - \\
\hline Fregata sp., unidentified frigatebird & 5 & - \\
\hline Anous minutus, Black Noddy & 1 & - \\
\hline Gygis candida, White Tern & 3 & - \\
\hline \multicolumn{3}{|l|}{ Land Birds } \\
\hline Gallirallus sp., undescribed flightless rail & 17 & - \\
\hline Gallicolumba sp. 1, undescribed large ground-dove & 3 & - \\
\hline Gallicolumba sp. 2, undescribed small ground-dove & 4 & 1 \\
\hline \multicolumn{3}{|l|}{ Nonnative Birds } \\
\hline Gallus gallus, Chicken & 15 & - \\
\hline \multicolumn{3}{|l|}{ Totals (bones/species) } \\
\hline Seabirds & $28 / 5$ & $2 / 1$ \\
\hline Land birds & $24 / 3$ & $1 / 1$ \\
\hline Nonnative birds & $15 / 1$ & - \\
\hline
\end{tabular}

The six taxa of seabirds identified are all widespread in East Polynesia today and have been recorded in modern times on Rurutu or nearby islands in the Australs (Pratt et al. 1987, Raust et al. 2002). No bones of procellariids (shearwaters, petrels, and relatives) were recovered, unlike at most other EEP middens (Steadman 2006:table 15-3).

Each of the three species of land birds from Peva is extinct. The most common is a medium-sized extinct rail, Gallirallus undescribed sp., represented by four femora, 11 tibiotarsi, and two tarsometatarsi. This rail presumably was flightless as in other East Polynesian species of Gallirallus (Steadman 1987, Kirchman and Steadman 2006, 2007) but is known only from leg elements. The two other extinct land birds are ground-doves (Gallicolumba undescribed sp. 1, a relatively large species represented by a humerus and two tibiotarsi, and the smaller Gallicolumba undescribed sp. 2, known from a scapula, humerus, and three ulnae). No species in either Gallirallus or Gallicolumba has been recorded previously from the Austral Islands, whether in a modern or prehistoric context.

The only nonnative species of bird present prehistorically on Rurutu (or elsewhere in
East Polynesia) is the chicken, bones of which were confined at Peva to the EEP deposit. Elsewhere in East Polynesia, chicken bones typically are recovered in midden deposits throughout the prehistoric cultural sequence (Steadman 2006:83, 221). At Peva, however, the LEP deposit is associated with a marae and abundant, high-status feasting foods, namely sea turtle and pig (Bollt 2008a:table 2.2).

All but three of the 70 bird bones are from Layer D, which is the deepest and oldest (EEP) cultural stratum at Peva. Of the 30 bones of seabirds, 28 are from the EEP deposit, which also yielded 24 of the 25 bones of extinct land birds (rail, two ground-doves) and all 15 chicken bones. The only species recorded exclusively from the LEP deposits is the tropicbird Phaethon rubricauda, a seabird that still nests on Rurutu.

Bird bones are a minor part of the vertebrate NISP at the Peva dune site in either time period, decreasing from $2.1 \%$ (EEP) to $0.4 \%$ in the LEP period (Bollt 2008a:table 2). Fish are much more important than any other vertebrate component in the EEP deposit, whereas fish, sea turtle, and pig are codominant in the marae-related strata of the LEP period. 


\section{DISCUSSION}

\section{Prehistory of Birds}

Before our study, the only prehistoric land bird bone known from the Austral Islands was from a small excavation at the Atiahara site, Tubuai, by Richard Shutler in 1995. The Atiahara site is developed in an open, calcareous sand deposit with an EEP artifact assemblage (see Kirch 1986, 1996, Weisler 1994) that probably is contemporaneous with that of the Peva dune site. The bones from Atiahara are dominated by fish (Steadman 2006:table 7-11). The scarcity of bird bones $(0.2 \% \mathrm{NISP})$ and the fact that pig bones are nearly as frequent as rat bones suggest that recovery of small bones at Atiahara was less complete than at Peva.

The 11 bird bones from the Atiahara site represent seven species (Steadman 2006:table 7-12). The five species of seabirds (four extant; one exirpated, the prion Pachyptila sp.) also occur in EEP middens in the Cook Islands, the Marquesas, and Easter Island. Three species recorded from Atiahara were found as well at the Peva dune site (the tropicbird Phaethon lepturus, tern Gygis candida, and chicken Gallus gallus). The single land bird from Atiahara is a fruit-dove (Ptilinopus undescribed sp.) represented by a nearly complete tibiotarsus that differs much from those of the nearest congeneric species, $P$. rarotongensis to the west (Cook Islands) and $P$. buttoni to the southeast (Rapa [Steadman 2006:227-229]).

The only other prehistoric bird bones known from the Austral Islands are from Rurutu, where Gustav Paulay collected 12 associated bones of a petrel in a noncultural context (beneath a calcite layer) in Coconut Cave in August 1983. These bones are from a small species of Pterodroma such as $P$. nigripennis or P. cookii, the former being the most commonly recorded prehistoric seabird on Mangaia (Steadman 2006:table 7-3).

\section{Extinction and Biogeography}

Prehistoric Polynesians imported the pig (Sus scrofa), dog (Canis familiaris), chicken (Gallus gallus), and Pacific rat (Rattus exulans) to $\mathrm{Ru}-$ rutu, just as they did through most of East Polynesia. The possible role of these nonnative species in the extinction of native birds was discussed by Steadman (2006:405-417), who noted that deforestation and hunting also undoubtedly were involved in the depletion of birdlife.

The only indigenous land birds on $\mathrm{Ru}-$ rutu today are three widespread, semiaquatic species (the heron Egretta sacra, duck Anas superciliosa, and rail Porzana tabuensis) (Table $2)$. With the addition of three extinct species (the rail Gallirallus undescribed sp. and ground-doves Gallicolumba undescribed spp. 1 and 2), more species of land birds have been recorded on Rurutu than on any other island in the Australs. In the nearby Cook Islands, the rich fossil record of Mangaia (1,356 identified land bird bones from 17 sites) increased its land bird fauna from five to 20 species (Steadman 2006:table 7-3). Were comparably extensive bone deposits available on Rurutu (or any of the other four high islands in the group), the true species richness of land birds in the Australs probably would approach that of Mangaia.

Gallirallus undescribed sp. from Peva helps to round out the former distribution of this genus in East Polynesia, where it no longer exists. Extinct, flightless species of Gallirallus rails already have been described from the Cooks, Societies, and Marquesas, with multiple species per archipelago but only a single species per island. For ground-doves of the genus Gallicolumba, the only extant East Polynesian species are G. erythroptera in the Tuamotus and $G$. rubescens in the Marquesas. Prehistoric bones document that two species of Gallicolumba, one of them extinct, formerly existed in the Cooks, Societies, Marquesas, Tuamotus, and now, the Australs.

We note as well that a mandible and four other bone fragments of the flying fox (Pteropus tonganus) were identified from the EEP deposit at Peva, marking a new eastern limit for this species and for all pteropodid bats (Weisler et al. 2006). In East Polynesia, P. tonganus still exists only on Rarotonga and Mangaia in the Cook Islands (Hill 1979) but has been found in archaeological sites on Ma'uke (Walter 1998:79) and Aitutaki 
TABLE 2

Distribution of Indigenous Land Birds in the Tubuai (Austral) Islands

\begin{tabular}{|c|c|c|c|c|c|c|c|}
\hline Species & Tubuai & Rurutu & Rapa & Ra'ivavae & Rimatara & Maria & TOTAL \\
\hline Egretta sacra, Pacific Reef-Heron & M & M & M & M & M & M & 6 \\
\hline Anas superciliosa, Gray Duck & M & M & M & M & M & - & 5 \\
\hline Gallirallus undescribed sp., Rurutu Rail & - & $\mathrm{P}$ & - & - & - & - & 1 \\
\hline Porzana tabuensis, Sooty Crake & $\mathrm{M} / \mathrm{H}$ & $M$ & M & - & - & - & 3 \\
\hline Gallicolumba undescribed sp. 1, large ground-dove & - & $\mathrm{P}$ & - & - & - & - & 1 \\
\hline Gallicolumba undescribed sp. 2, small ground-dove & - & $\mathrm{P}$ & - & - & - & - & 1 \\
\hline Ptilinopus buttoni, Rapa Fruit-Dove & - & - & M & - & - & - & 1 \\
\hline Ptilinopus undescribed sp., fruit-dove & $\mathrm{P}$ & - & - & - & - & - & 1 \\
\hline Vini kublii, Rimatara Lorikeet & - & - & - & - & M & - & 1 \\
\hline Acrocephalus vaughani, Pitcairn Reed-Warbler & - & - & - & M & M & - & 2 \\
\hline Total species $(\mathrm{H}, \mathrm{M})$ & 3 & 3 & 4 & 3 & 4 & 1 & 6 \\
\hline Total species $(\mathrm{H}, \mathrm{M}, \mathrm{P})$ & 4 & 6 & 4 & 3 & 4 & 1 & 10 \\
\hline Number of prehistoric bird bones & 11 & 82 & 0 & 0 & 0 & 0 & 93 \\
\hline Number of native land bird bones & 1 & 25 & 0 & 0 & 0 & 0 & 26 \\
\hline Island area $\left(\mathrm{km}^{2}\right)$ & 45 & 38.5 & 22 & 21 & 18 & 1.3 & - \\
\hline Elevation $(\mathrm{m})$ & 422 & 389 & 633 & 437 & 95 & 5 & - \\
\hline Isolation ( $\mathrm{km}$ to nearest high island) & 180 & 145 & 505 & 180 & 145 & 200 & - \\
\hline
\end{tabular}

Note: No species of land birds have been recorded from Marotiri Rocks. H, historic record (past $200 \mathrm{yr}$ ), no longer survives; M, modern record, certainly or probably still survives; P, prehistoric record. Isolation values rounded to nearest $5 \mathrm{~km}$. From Petitot and Petitot (1975), Ehrhardt (1980), Holyoak and Thibault (1984), Pratt et al. (1987), Seitre and Seitre (1991), Steadman (2006:table 7-10), http://www.manu.pf/E_RURUTU.html (information compiled in Raust et al. [2002], and herein).

(Steadman 1991). The flying fox is likely to have occurred prehistorically on all high, substantial islands in the Cook-Austral chain, but we cannot rule out interisland transport of this species by people.

The early inhabitants at Peva relied primarily upon fish, which account for $82.2 \%$ of total NISP in the EEP deposit but only $33.9 \%$ in the LEP deposit (Bollt 2008a:table 2). As with other differences between the EEP and LEP periods, this should be interpreted in light of the ceremonial nature of the marae, where feasting during the LEP period accounts for the high-status, nonfish foods such as sea turtle and pig (Bollt $2008 a, b)$. The scarcity of bird bones in these late deposits probably is related in part to the elimination of some species by that time.

\section{Ethnography}

The Australs and the southern Cooks were once so famous for their parakeet feathers that nineteenth-century Tahitians called them the Paroquet [parakeet] Islands, or Fenua-'ura ("Red Land") (Henry 1928:464). The name
"Red Land" probably refers to Kuhl's Lorikeet (Vini kublii), also called the Rimatara Lorikeet (Pratt et al. 1987), because it had been regarded as endemic to that island. Henry (1928:385) wrote, "The vini-'ura [Tahitian for red parakeet], a whistling parakeet of Rimatara (Austral Islands), of red, yellow, blue, and green plumage, was the shadow of (the god) Ta'aroa." Species of vini probably were found throughout the Cooks and Australs in prehistory. In fact, three species of $V i n i$ are known to have occurred on single islands in the three East Polynesian archipelagos (Cooks, Societies, and Marquesas) that have substantial records of prehistoric birds (Steadman 2006:345, 347, 348). In the southern Cook Islands, V. kublii is found prehistorically on Atiu and Mangaia, with Mangaia also having the two larger, extinct species $V$. vidivici and $V$. sinotoi, which are known only from bones in EEP middens or precultural deposits.

A more widespread source of red feathers in East Polynesia was the tropicbird Phaethon rubricauda. Morrison (1935:217-219) described expeditions up the cliff faces of 
Tahiti, where men would capture the tropicbird by hand, pluck out the two red central tail feathers, and then release it. On Mangaia in the 1980s and 1990s, Steadman observed boys and young men capturing and eating $P$. rubricauda, as well as saving its red tail feathers. Morrison also wrote about how the man-o'-war, or frigatebird (Fregata ariel, $F$. minor), was snared on Tahiti for its prized black tail feathers but never eaten. On Mangaia, frigatebirds do not seem to be valued much for their feathers but are eaten if available.

\section{ACKNOWLEDGMENTS}

For help in data analysis, we thank Jessica Oswald. For help during fieldwork, we thank Pierre Vérin; the community of Rurutu; its mayor, Frédéric Rivéta; the proprietor of the land on which the excavation took place, Fernand Ro'omata'aroa; Pierre Atai, Ingride Drollet, and their sons Takiri and Tapu; and of course Bollt's coexcavator, assistant, and friend, Papua. Research permits were kindly furnished by the government of French Polynesia, namely Louise Pelzter, and Henri Marchesi of the Service de la Culture et du Patrimoine and the Musée de Tahiti et ses Iles. For comments that improved the manuscript, we thank Andrew Kratter and two anonymous reviewers.

\section{Literature Cited}

Allen, M. S., and S. E. Schubel. 1990. Recent archaeological research on Aitutaki, southern Cooks: The Moturakau Rockshelter. J. Polynesian Soc. 99:265-295.

Allen, M. S., and D. W. Steadman. 1990. Excavations at the Ureia site, Aitutaki, southern Cook Islands: Preliminary results. Archaeol. Oceania 25:24-37.

Allen, M. S., and R. Wallace. 2007. New evidence from the East Polynesian gateway: Substantive and methodological results from Aitutaki, southern Cook Islands. Radiocarbon 49:1163-1179.

Banks, J. 1962. The Endeavor Journal of Joseph Banks, 1768-1771. J. C. Beaglehole, ed. Angus and Robertson, Sydney.
Bollt, R. 2008a. Excavations in Peva Valley, Rurutu, Austral Islands (East Polynesia). Asian Perspect. 47:156-187.

- 2008b. Peva: The archaeology of an Austral Island settlement. Bishop Mus. Bull. Anthropol. 12.

Bonneville, A., R. Suave, L. Audin, V. Clouard, L. Dosso, P. Y. Gillot, P. Janney, K. Jordhal, and K. Ma'ama'atuaiahutapu. 2002. Arago Seamount: The missing hotspot found in the Austral Islands. Geology 30:1023-1026.

Cook, J. 1955. The voyage of the Endeavor, 1768-1771. J. C. Beaglehole, ed. Hakluyt Society, Cambridge, United Kingdom.

Dickinson, W. R. 1998. Geomorphology and geodynamics of the Cook-Austral IslandSeamount Chain in the South Pacific Ocean: Implications for hotspots and plumes. Int. Geol. Rev. 40:1039-1075.

Ehrhardt, J. P. 1980. L'avifaune de Tubuaï. Cah. l'Indo Pac. 2:271-288.

Henry, T. 1928. Ancient Tahiti. Bernice P. Bishop Mus. Bull. 48.

Hill, J. E. 1979. The flying fox Pteropus tonganus in the Cook Islands and on Niue Island, Pacific Ocean. Acta Theriol. 24:115122.

Holyoak, D. T., and J.-C. Thibault. 1984. Contribution a l'étude des oiseaux de Polynésie Orientale. Mem. Mus. Natl. Hist. Nat. Sér. A, Zool. 127:1-209.

Kirch, P. V. 1986. Rethinking East Polynesian prehistory. J. Polynesian Soc. 95:940.

. 1996. Late Holocene humaninduced modifications to a central Polynesian island ecosystem. Proc. Natl. Acad. Sci. U.S.A. 93:5296-5300.

Kirch, P. V., D. W. Steadman, V. L. Butler, J. Hather, and M. Weisler. 1995. Prehistory and human ecology in eastern Polynesia: Excavations at Tangatatau Rockshelter, Mangaia, Cook Islands. Archaeol. Oceania 30:47-65.

Kirchman, J. J., and D. W. Steadman. 2006. New species of rails (Aves: Rallidae) from an archaeological site on Huahine, Society Islands. Pac. Sci. 60:281-297.

. 2007. New species of extinct rails 
(Aves: Rallidae) from archaeological sites in the Marquesas Islands, French Polynesia. Pac. Sci. 61:145-163.

Maury, R. C., C. Guille, H. Guillou, S. Blair, C. Chauvel, and R. Brouse. 2000. Carte geologique "Rurutu et Tubuai" Polynesie, notice explicative de la Feuille Rurutu et Tubuai a 1/25000 (Polynesie Francaise, Archipel des Australes). Editions du BRGM, Orleans, France.

Morrison, J. 1935. The Journal of James Morrison, boatswain's mate of the Bounty, describing the mutiny \& subsequent misfortunes of the mutineers, together with an account of the island of Tahiti. With an introduction by Owen Rutter and five engravings by Robert Gibbings. O. Rutter, ed. The Golden Cockerel Press, London.

ORSTOM. 1993. Atlas de la Polynésie française. ORSTOM, Paris.

Petitot, C., and F. Petitot. 1975. Observations ornithologiques dans l'Atoll de Manihi (Archipel des Tuamotu) et dans l'ile de Tubuai (Australes). Oiseau Rev. Fr. Ornithol. 45:83-88.

Pratt, H. D., P. L. Bruner, and D. G. Berrett. 1987. A field guide to the birds of Hawaii and the tropical Pacific. Princeton University Press, Princeton, New Jersey.

Raust, P., G. Sanford, Y. Gentilhomme, and A. Varney. 2002. http://www.manu.pf/E _RURUTU.html.
Seitre, R., and J. Seitre. 1991. Causes de disparition des oiseaux terrestres de Polynésie française. SPREP Occas. Pap. Séries 8, South Pacific Comm., Nouméa, New Caledonia.

Steadman, D. W. 1987. Two new species of rails (Aves: Rallidae) from Mangaia, southern Cook Islands. Pac. Sci. 41:27-43.

- 1991. Extinct and extirpated birds from Aitutaki and Atiu, southern Cook Islands. Pac. Sci. 45:325-347.

. 2006. Extinction and biogeography of tropical Pacific birds. University of Chicago Press, Chicago.

Stoddart, D. R., and T. Spencer. 1987. Rurutu reconsidered: The development of makatea topography in the Austral Islands. Atoll Res. Bull. 297.

Walter, R. 1998. Anai'o: The archaeology of a fourteenth century Polynesian community in the Cook Islands. N. Z. Archaeol. Assoc. Monogr. 22.

Weisler, M. I. 1994. The settlement of marginal Polynesia: New evidence from Henderson Island. J. Field Archaeol. 21:83102.

Weisler, M. I., R. Bollt, and A. Findlater. 2006. A new eastern limit of the Pacific Flying Fox, Pteropus tonganus (Chiroptera: Pteropodidae) in prehistoric Polynesia: A case of possible human transport and extirpation. Pac. Sci. 60:403-411. 
